
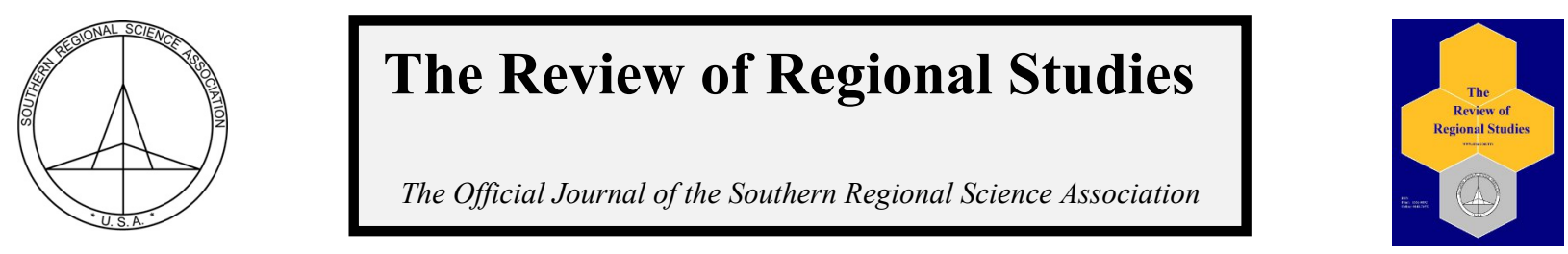

\title{
Two-Region DSGE Analysis of Regionally Targeted Fiscal Policy ${ }^{*}$
}

\author{
Kenichi Tamegawa
}

School of Commerce, Meiji University, Japan

\begin{abstract}
In this paper, we explain how to construct a dynamic stochastic general equilibrium model consisting of $N$ regions, and use the two-region version of the model to simulate the effects of fiscal policy on the economy. Our policy simulation shows that the fiscal multiplier depends on which government (local or central) implements the fiscal policy and where the policy is implemented.
\end{abstract}

Keywords: regional DSGE model, fiscal policy, fiscal multipliers

JEL Codes: E30, E62, R10

\section{INTRODUCTION}

The financial crisis in 2008 led to an economic recession in many countries. This recession, in turn, forced many governments around the world to implement a large fiscal stimulus. As a result, the effect of fiscal policy on the economy has become a popular topic in macroeconomics. Moreover, more recently many countries experienced fiscal crises. Although the reasons for these fiscal crises might differ from country to country, their negative impact is similar.

In order to study the effects of economic policy on the macroeconomy, we often use a dynamic stochastic general equilibrium (DSGE) model. In most of these models, the unit considered is a "country," and the country usually consists of a single region. However, in reality, most countries are divided into many regions. Therefore, the effects of a fiscal policy cannot be uniform across regions if each region's economic structure is different. To consider this possibility, we split a country into several regions and construct a tractable regional DSGE model. We investigate the manner and extent to which fiscal policy affects our model economy. In addition, our aim is to introduce the usefulness of DSGE models to regional scientists. Note that a DSGE framework such as ours has the advantage of being easy to apply, particularly to a forward-looking dynamic model, and can be run on well-established computer programs (such as DYNARE). Therefore, regional scientists who are interested in DSGE models can easily build the model and implement a policy simulation analysis.

Fiscal policy studies using standard DSGE models show the fiscal multiplier to be small because of a negative consumption response through negative wealth effects. However, many

\footnotetext{
* I am grateful to two anonymous referees and editor Michael L. Lahr for their helpful comments. This work was supported by a Grant-in-Aid for Scientific Research (No. 22330090) from the Ministry of Education, Culture, Sport, Science and Technology, Japan.

Tamegawa is an Instructor in the Department Commerce at Meiji University, 1-1 Kanda-Surugadai, Chiyoda-ku, Tokyo 1018301, Japan. E-mail: tamegawa@kisc.meiji.ac.jp
}

C) Southern Regional Science Association 2013.

ISSN 1553-0892, 0048-749X (online)

www.srsa.org/rrs 
empirical studies using a vector auto regressive (VAR) model have indicated a positive consumption response to fiscal shock. In recent studies, while Beetsma and Giuliodori (2011) confirm a positive consumption response to fiscal shock, Ramey (2011) finds a negative response. We construct our model allowing for a positive consumption response.

Our main result is that the magnitude of the fiscal multiplier depends on which government implements the fiscal policy and where the policy is implemented. This implies that to measure fiscal multipliers, we have to consider heterogeneity across regions.

In standard DSGE models, there are often cases in which the effect of fiscal policy on consumption is negative because of a negative wealth effect (for example, see Baxter and King, 1993). However, many empirical analyses suggest a positive consumption response to government spending shocks. ${ }^{1}$ In order to obtain a positive response, we need to incorporate several extensions to DSGE models. These include "deep habit" (Ravn et al., 2006), a utility function that strengthens the complementarity between consumption and labor (Linnemann, 2006; Monacelli et al., 2010), and non-Ricardian households (Galí et al., 2007). In this paper, we assume the existence of non-Ricardian households, which is frequently assumed in fiscal studies. Under this assumption, non-Ricardian households earn a wage and work in the same manner as Ricardian households.

The regional DSGE model constructed in this paper is similar to models that describe the economy of a currency area. These currency union models are developed by, for example, Benigno (2004), Lombardo (2006), and Galí and Monacelli (2008), and they analyze an optimal policy design in that framework. Our model, however, has a central government that is responsible for managing the whole region, and this is its main difference from currency union models. Therefore, we can analyze the effects of central and local government spending on the economy separately. The structures of the central and local governments are different from each other, for example, in terms of solvency. Economic structures also differ from region to region. This yields the conjecture that the fiscal multiplier depends on who implements the policy and where this is done. Only the DSGE model with heterogeneous regions will have the answer to this interesting question.

When focusing on economic geography, such as agglomeration, integration, and so on, our model may be compared to the so-called New Economic Geography (NEG) models. ${ }^{2}$ NEG models are quite useful and insightful when analyzing economic geography. Then what is the advantage of DSGE modeling? We believe it is the ease with which one can incorporate agents' forward-looking behavior. The dynamics of forward-looking behavior is one of important factors in recent macroeconomics. The effects of economic policy depend significantly on agents' expectations of the future. It should be noted that the tractability of forward-looking dynamics can be gained at the cost of imperfect mobility for agents. This assumption is unattractive for regional analysis. However, an analysis of a dynamic regional model based on DSGE modeling is needed, even if the results are quite similar to NEG models, at least with respect to obtaining robustness in policy analyses.

As stated above, many countries have experienced a fiscal crisis. The recent large fiscal expansion in many countries has caused large amounts of government debt, which might account

\footnotetext{
${ }^{1}$ A positive consumption response for fiscal expansion has been empirically confirmed by Blanchard and Perotti (2002) and Mountford and Uhlig (2009) using US data. Beetsma and Giuliodori (2011) have confirmed it in EU countries.

${ }^{2}$ For NEG models, see Fujita and Krugman (2004) and Fujita and Mori (2005).
}

(c) Southern Regional Science Association 2013. 
for the crises. On the other hand, a loose stance on fiscal policy might also bring about such a crisis, as in the case of Greece. Whatever the reason, a fiscal crisis can be considered to be a situation in which investors do not expect the government to repay its debt. In such a circumstance, risk premiums soar, causing interest rates to rise, and ultimately resulting in an economic recession. In our model, we interpret the agents' expectation that the government will default as an increase in expected default probability. Our simulation results confirm the negative effects of the output.

Our paper is organized as follows. Section 2 explains the structure of our regional DSGE model. In Section 3, we set the parameter values, and in Section 4, we show impulse responses to fiscal policy shock. In Section 5, we illustrate a fiscal crisis using our model. Finally, Section 6 concludes the paper.

\section{THE MODEL}

Our model is simply a version of standard real business cycle models. We represent the number of regions as $\mathbf{N}=\{\mathbf{1}, \mathbf{2}, \ldots, \boldsymbol{N}\}$. We assume that the population size for each region is unity (therefore, the population size of the whole economy is $\boldsymbol{N}$ ). Our economy has Ricardian households, non-Ricardian households, firms, bankers, and the government. Bankers collect deposits and distribute them to firms and the local and central governments by imposing interest rates. The number of non-Ricardian households and bankers is denoted by $\omega_{-} i$ and $\omega_{-}(\mathrm{B}, \mathrm{i})$, respectively, in each region.

\subsection{Firms}

We assume that each region produces the same output, and therefore, a single output market exists. We also assume that the labor market is separated in each region. ${ }^{3}$ The production function for each region $i$ is as follows:

$$
Y_{t}^{i}=e^{z_{t}^{i}} e^{z_{t}^{m}}\left(K_{t}^{i}\right)^{\alpha_{i}}\left[\left(1-\omega_{B, i}\right) h_{t}^{i}\right]^{1-\alpha_{i}}\left(K_{t}^{g, i}\right)^{\eta_{i}}
$$

where $Y_{t}^{i}$ denotes output; $K_{t}^{i}$, capital stock; $h_{t}^{i}$, hours worked; and $K_{t}^{g, i}$, social capital stock. The super script $i$ represents the region. In Eq (1), $z_{t}^{i}$ and $z_{t}^{m}$ represent the region-specific and macro shocks, respectively, with a mean of zero. The first-order condition yields, for all $i \in \mathbf{N}$,

$$
\left(1-\omega_{B, i}\right) w_{t}^{i}=\left(1-\alpha_{i}\right) \frac{Y_{t}^{i}}{h_{t}^{i}}
$$

The rental costs for capital, $r_{t}^{i}$, are

$$
r_{t}^{i}=\alpha_{i} \frac{Y_{t}^{i}}{K_{t}^{i}}
$$

\subsection{Households}

\subsubsection{Ricardian (optimizing) households}

The Ricardian households in region $i$ consume goods and provide labor such that their inter-temporal utility function is maximized, subject to the following budget constraint:

(4) $d_{t+1}^{i}=R_{t-1}^{D} d_{t}^{i}+w_{t}^{i} h_{t}^{i}-c_{t}^{o, i}-t_{t}^{i}-t_{t}^{C}$,

\footnotetext{
${ }^{3}$ We assume that households cannot move to a different region.
} 
where $d_{t}^{i}$ represents deposits; $R_{t}^{D}$, the interest rate for deposits; $c_{t}^{o, i}$, the consumption for optimizing households; $t_{t}^{i}$, the lump-sum tax imposed by the local government; and $t_{t}^{C}$, the lumpsum tax imposed by the central government. The objective function for the households in region $i$ is as follows:

$$
E_{0} \sum_{t=0}^{\infty} \beta^{t}\left\{\log \left(c_{t}^{o, i}-b \bar{c}_{t-1}^{o, i}\right)+\theta_{i} \log \left(1-h_{t}^{i}\right)\right\},
$$

where $\bar{c}_{t}^{o, i}$ denotes the consumption externality, defined as the average consumption for the Ricardian households $\left(\bar{c}_{t}^{o, i}=c_{t}^{o, i}\right)$. The first-order conditions are

$$
\begin{gathered}
\frac{1}{c_{t}^{o, i}-b c_{t-1}^{o, i}}-\lambda_{t}^{i}=0, \\
\lambda_{t}^{i}-E_{t}\left(\beta R_{t}^{D} \lambda_{t+1}^{i}\right)=0, \\
\frac{\theta_{i}}{1-h_{t}^{i}}-\lambda_{t}^{i} w_{t}^{i}=0 .
\end{gathered}
$$

As seen above, we do not assume costless labor mobility. This is an unusual assumption for an NEG approach. Our model is designed to analyze how a temporal policy change affects an economy: the steady state of our economy before and after the change remains the same. Therefore, we assume that the size of our policy change is not sufficiently large for agents to alter their location.

\subsubsection{Non-Ricardian (rule-of-thumb) households}

Non-Ricardian, or rule-of-thumb households consume their disposable income every period. Therefore,

$$
c_{t}^{r, i}=w_{t}^{i} h_{t}^{i}-t_{t}^{i}-t_{t}^{C}
$$

where $c_{t}^{r, i}$ denotes the consumption for non-Ricardian households. Following Galí et al. (2007), we assume that non-Ricardian households earn wages and work in the same manner as Ricardian households.

\subsection{Bankers}

Bankers collect deposits from Ricardian households, lend these to firms and governments, and consume goods. In this situation, bankers become borrowers for households and firms, and the government becomes the borrower for bankers. Borrowers pay interest rate to lenders. The national deposits are represented as

$$
D_{t+1}=\sum_{i \in \mathbf{N}}\left(1-\omega_{i}-\omega_{B, i}\right) d_{t+1}^{i} .
$$

The budget constraint of bankers is as follows: 


$$
\begin{aligned}
(9) C_{t}^{B}+\sum_{i \in \mathbf{N}} B_{t+1}^{i} & +B_{t+1}^{c}+R_{t-1}^{d} D_{t}+\sum_{i \in \mathbf{N}} Q_{t}^{i} K_{t+1}^{i}+\sum_{i \in \mathbf{N}} I_{t}^{i}+\sum_{i \in \mathbf{N}} t_{t}^{i}+n t_{t}^{C} \\
= & \sum_{i \in \mathbf{N}} r_{t}^{k, i} K_{t}^{i}+\sum_{i \in \mathbf{N}} Q_{t}^{i}\left\{(1-\delta) K_{t}^{i}+I_{t}^{i}\left[1-\Phi\left(I_{t}^{i} / I_{t-1}^{i}\right)\right]\right\}+D_{t+1}+\sum_{i \in \mathbf{N}} R_{t-1}^{i} B_{t}^{i} \\
+ & R_{t-1}^{c} B_{t}^{c},
\end{aligned}
$$

where $C_{t}^{B}$ represents the consumption of bankers; $Q_{t}^{i}$, the value of capital goods; $R_{t}^{i}$, the interest rate for local government bonds; $R_{t}^{c}$, the interest rate for central government bonds; $I_{t}^{i}$, capital goods investment; $B_{t}^{i}$, the bonds for local government $i$; and $B_{t}^{c}$, the central government bonds. ${ }^{4}$ The function $\Phi\left(I_{t}^{i} / I_{t-1}^{i}\right)$ represents adjustment costs. ${ }^{5}$ Note that in Eq (9), the left-hand side represents expenditure and the right-hand side represents receipts. Assuming a logarithmic-type temporal utility, the maximization problem of bankers is reduced to maximizing the following Lagrangean:

$$
\begin{aligned}
& E_{0}\left\{\sum _ { t = 0 } ^ { \infty } ( \beta _ { B } ) ^ { t } \left[\ln \left(C_{t}^{B}\right)\right.\right. \\
& -\lambda_{t}^{B}\left[C_{B, t}+\sum_{i \in \mathbf{N}} B_{t+1}^{i}+B_{t+1}^{c}+R_{t-1}^{d} D_{t}+\sum_{i \in \mathbf{N}} I_{t}^{i}+\sum_{i \in \mathbf{N}} t_{t}^{i}+n t_{t}^{C}-\sum_{i \in \mathbf{N}} r_{t-1}^{k, i} K_{t}^{i}-D_{t+1}\right. \\
& \left.\left.-\sum_{i \in \mathbf{N}} \mathbf{1}_{t}^{i} R_{t-1}^{i} B_{t}^{i}-\mathbf{1}_{t}^{c} \Gamma_{t}^{c} R_{t-1}^{c} B_{t}^{c}-\sum_{i \in \mathbf{N}} Q_{t}^{i}\left(K_{t+1}^{i}-(1-\delta) K_{t}^{i}-I_{t}^{i}\left[1-\Phi\left(I_{t}^{i} / I_{t-1}^{i}\right)\right]\right]\right]\right\}
\end{aligned}
$$

where $\lambda_{t}^{B}$ denotes the Lagrange multiplier of Eq (9) and $\mathbf{1}_{t}^{i}$ and $\mathbf{1}_{t}^{c}$ denote the indicator functions, defined as follows:

$$
\begin{aligned}
& \mathbf{1}_{t}^{i}=\left\{\begin{array}{lc}
1 & \text { if the local government } \mathrm{i} \text { at } \mathrm{t} \text { does not default } \\
0 & \text { otherwise }
\end{array}\right. \\
& \mathbf{1}_{t}^{c}=\left\{\begin{array}{cc}
1 & \text { if the central government at } t \text { does not default } \\
0 & \text { otherwise }
\end{array} .\right.
\end{aligned}
$$

We assume that the conditional probabilities that the local government $i$ at $t$ and the central government at $t$ default are $p_{t}^{i}$ and $p_{t}^{c}$, respectively. The first order-conditions are as follows:

$$
\begin{gathered}
\frac{1}{C_{t}^{B}}-\lambda_{t}^{B}=0, \\
\lambda_{t}^{B}-E_{t}\left[\beta_{B} \lambda_{t+1}^{B} R_{t}^{i}\left(1-p_{t+1}^{i}\right)\right]=0, \\
\lambda_{t}^{B}-E_{t}\left[\beta_{B} \lambda_{t+1}^{B} R_{t}^{c}\left(1-p_{t+1}^{c}\right)\right]=0, \\
\lambda_{t}^{B}-E_{t}\left[\beta_{B} \lambda_{t+1}^{B} R_{t}^{d}\right]=0, \\
Q_{t}^{i} \lambda_{t}^{B}-E_{t}\left(\beta_{B}\left[\lambda_{t+1}^{B} Q_{t+1}^{i}(1-\delta)+\lambda_{t+1}^{B} r_{t+1}^{i}\right]\right)=0,
\end{gathered}
$$

\footnotetext{
${ }^{4}$ We assume that bankers are homogeneous. Therefore, the bankers' problem is expressed in terms of an aggregated value.

${ }^{5}$ The function $\Phi\left(I_{t}^{i} / I_{t-1}^{i}\right)$ has been used by Christiano et al. (2005). In this function, capital stock is adjusted gradually. It has been frequently used to increase the fit to the actual economy in many papers.
}

(C) Southern Regional Science Association 2013. 


$$
\lambda_{t}^{B}-\lambda_{t}^{B} Q_{t}^{i}\left\{1-\Phi^{\prime}\left(\frac{I_{t}^{i}}{I_{t-1}^{i}}\right)\left(\frac{I_{t}^{i}}{I_{t-1}^{i}}\right)-\Phi\left(\frac{I_{t}^{i}}{I_{t-1}^{i}}\right)\right\}-E_{t}\left(\beta_{B} \lambda_{t+1}^{B} Q_{t+1}^{i} \Phi^{\prime}\left(\frac{I_{t}^{i}}{I_{t-1}^{i}}\right)\left(\frac{I_{t}^{i}}{I_{t-1}^{i}}\right)^{2}\right)=0
$$

To obtain the above equations, we consider the following. Explicitly denoting the information set at $t$ as $\Omega_{t}$, and assuming $\Omega_{t} \subset \Omega_{t+1}$ for any random vector $x_{t}$, we get

$$
\begin{aligned}
E_{t}\left[\mathbf{1}_{t+s}^{i} x_{t+s}\right] & =E\left[\mathbf{1}_{t+s}^{i} x_{t+s} \mid \Omega_{t}\right] \\
& =E\left[E\left[\mathbf{1}_{t+s}^{i} x_{t+s} \mid \Omega_{t+s}\right] \mid \Omega_{t}\right] \\
& =E\left[E\left[\mathbf{1}_{t+s}^{i} \mid \Omega_{t+s}\right] x_{t+s} \mid \Omega_{t}\right] \\
& =E\left[\left(1-p_{t+s}^{i}\right) x_{t+s} \mid \Omega_{t}\right],
\end{aligned}
$$

where $E\left[\mathbf{1}_{t+s}^{i} \mid \Omega_{t+s}\right]$ is equal to the probability, conditional on $\Omega_{t+s}$, that the local government $i$ at $t+s$ does not default. These equations can be simplified by defining a stochastic discount factor as $\Lambda_{t+1, t}=\beta_{B} \frac{C_{t}^{B}}{C_{t+1}^{B}}$. For all $i \in \mathbf{N}$,

$$
\begin{gathered}
1-E_{t}\left[\Lambda_{t+1, t} R_{t}^{i}\left(1-p_{t+1}^{i}\right)\right]=0, \\
1-E_{t}\left[\Lambda_{t+1, t} R_{t}^{c}\left(1-p_{t+1}^{c}\right)\right]=0, \\
1-E_{t}\left[\Lambda_{t+1, t} R_{t}^{d}\right]=0, \\
Q_{t}^{i}-E_{t}\left(\Lambda_{t+1, t}\left[Q_{t+1}^{i}(1-\delta)+r_{t+1}^{i}\right]\right)=0, \\
Q_{t}^{i}\left\{1-\Phi^{\prime}\left(I_{t}^{i} / I_{t-1}^{i}\right)\left(I_{t}^{i} / I_{t-1}^{i}\right)-\Phi\left(I_{t}^{i} / I_{t-1}^{i}\right)\right\}+E_{t}\left(\Lambda_{t+1, t} Q_{t+1}^{i} \Phi^{\prime}\left(I_{t+1}^{i} / I_{t}^{i}\right)\left(I_{t+1}^{i} / I_{t}^{i}\right)^{2}\right)=1 .
\end{gathered}
$$

\subsection{Aggregation}

For region $i$, we represent the non-banker total consumption and the total tax for the local government by $C_{t}^{i}$ and $T_{t}^{i}$, respectively:

$$
\begin{gathered}
C_{t}^{i}=\omega_{i} c_{t}^{r, i}+\left(1-\omega_{i}-\omega_{B, i}\right) c_{t}^{o, i}, \\
T_{t}^{i}=t_{t}^{i} .
\end{gathered}
$$

In addition, we represent the total tax for the central government and total government expenditure for the central government by $T_{t}^{C}$ and $G_{t}^{C}$, respectively:

$$
\begin{gathered}
T_{t}^{C}=N t_{t}^{C}, \\
G_{t}^{C}=\sum_{i \in \mathbf{N}} G_{t}^{C, i} .
\end{gathered}
$$

\subsection{Central Government and Local Government}

For the local government of region $i \in N$, the budget constraint is

$$
B_{t+1}^{i}=R_{t-1}^{i} B_{t}^{i}+G_{t}^{i}-T_{t}^{i},
$$

For the central government, the budget constraint is

$$
B_{t+1}^{C}=R_{t-1}^{C} B_{t}^{C}+G_{t}^{C}-T_{t}^{C}
$$

(C) Southern Regional Science Association 2013. 
We assume the following equations as the tax and fiscal expenditure rules:

$$
\begin{gathered}
\log t_{t}^{i}=\text { const. }+\xi_{b}^{i} \log B_{t}^{i}, \\
\log t_{t}^{C}=\text { const. }+\xi_{b} \log B_{t}^{C}, \\
\log G_{t}^{i}=\text { const. }+\rho_{i} \log G_{t-1}^{i}+\varepsilon_{t}^{i}, \\
\log G_{t}^{c}=\text { const. }+\rho_{c} \log G_{t-1}^{c}+\varepsilon_{t}^{c},
\end{gathered}
$$

where "const." in each equation denotes the constant value consistent with the steady-state value. We assume that the non-default rate for each region and the central government, $\left(1-p_{t}^{i}\right)$ and $\left(1-p_{t}^{c}\right)$, respectively, decreases with $B_{t}^{i}$ and $B_{t}^{c}$ in the following manner.

(31) $\log \left(1-p_{t}^{i}\right)=$ const. $-v_{i} \log B_{t}^{i}$, for all $i \in \mathbf{N}$,

$$
\log \left(1-p_{t}^{c}\right)=\text { const. }-v_{c} \log B_{t}^{c} .
$$

We assume that social capital stock is accumulated as follows

$$
K_{t+1}^{g, i}=\left(1-\delta_{g}\right) K_{t}^{g, i}+G_{t}^{C, i}+G_{t}^{i} .
$$

\subsection{Equilibrium Condition} as follows:

In our model, there is only one good. Therefore, the equilibrium condition for this good is

$$
\sum_{i \in \mathrm{N}} Y_{t}^{i}=\sum_{i \in \mathrm{N}}\left(C_{t}^{i}+I_{t}^{i}+G_{t}^{i}+G_{t}^{C, i}\right)+C_{t}^{B} .
$$

The time frequency of our model is annual to avoid short-term rigidities such as a sticky price. The other reason for the annual frequency is that a government's accounting term is annual.

\section{PARAMETER SETTINGS}

We simulate the model constructed in the previous section. For simplicity, we consider a case of two regions $(N=2)$. In this section, we set the parameter values for a two-region version of our model.

The parameter values are summarized in Table 1. The parameters for the discount rate and habit formation are common to both regions and are set to $\beta=\beta_{B}=0.98$ and $b=0.8$. The physical capital and social capital depreciation rate are both set to 0.08 . The steady-state value of the output is normalized to 1 for each region. The steady-state hours worked is set to 0.5 in both regions. The steady-state value of consumption share, the central government's spending share, and the local government's spending share are set to $0.6,0.05$, and 0.08 , respectively. The local government's debt to regional output ratio in the steady state is 1 for both regions. The central government's debt to national output ratio is similarly 1 . The local tax and central tax, which we assume to be common to both regions, are calculated as 0.11 and 0.07 , respectively, given the above parameters and the steady-state version of our model. The default rates for the central government and the governments of region 1 and region 2 are set to $0.001,0.01$, and 0.03 , respectively. As a tentative value, the rate for the central government is assigned a small number, assuming that the central government is more credible. The difference in the default value between regions reflects the fact that social capital makes region 1 more productive and therefore less likely to default than region 2 . The adjustment cost for investment is set to 15 for both

(C) Southern Regional Science Association 2013. 
Table 1: Parameter Settings

\begin{tabular}{|c|c|c|c|c|}
\hline & \multicolumn{2}{|c|}{ Region } & \multirow[t]{2}{*}{ Central } & \multirow[t]{2}{*}{ Comments } \\
\hline & 1 & 2 & & \\
\hline$\alpha_{i}$ & 0.25 & 0.42 & - & Capital share \\
\hline$\eta_{i}$ & 0.20 & 0.00 & - & Social capital productivity \\
\hline$\beta$ & 0.98 & 0.98 & - & Discount rate \\
\hline$B$ & 0.80 & 0.80 & - & Habit persistence \\
\hline$\delta$ & 0.08 & 0.08 & - & Depreciation rate \\
\hline$\delta_{g}$ & 0.08 & 0.08 & - & Depreciation rate for social capital \\
\hline$h_{i}$ & 0.50 & 0.50 & & Steady-state hour worked \\
\hline$\omega_{i}$ & 0.40 & 0.30 & - & Population share of non-Ricardian households \\
\hline$\omega_{B, i}$ & 0.005 & 0.005 & & Population share of bankers \\
\hline$\xi_{i}$ & 0.90 & 0.90 & - & Elasticity of local tax with respect to own debt \\
\hline$\xi_{c}$ & - & - & 0.90 & Elasticity of central tax with respect to own debt \\
\hline$\rho_{i}$ & 0.66 & 0.66 & - & Persistency for local government expenditure \\
\hline$\rho_{c}$ & 0.66 & 0.66 & - & Persistency for central government expenditure \\
\hline$v_{i}$ & 0.03 & 0.10 & - & Elasticity of risk premium with respect to own debt \\
\hline$v_{c}$ & - & - & 0.00 & Elasticity of risk premium with respect to own debt \\
\hline$G^{i} / Y^{i}$ & 0.08 & 0.08 & - & Share of local government expenditure \\
\hline$G^{c, i} / Y^{i}$ & 0.05 & 0.05 & - & Share of central government expenditure \\
\hline$B^{i} / Y^{i}$ & 1.00 & 1.00 & - & Local government debt to regional output ratio \\
\hline$B^{c} /\left(Y^{l}+Y^{2}\right)$ & - & - & 1.00 & $\begin{array}{l}\text { Central government debt to output ratio for central } \\
\text { debt }\end{array}$ \\
\hline$C^{i} / Y^{i}$ & 0.60 & 0.60 & - & Share of consumption \\
\hline
\end{tabular}

regions. The elasticity of the central and local government taxes with respect to debt is set to 0.9 . The persistency parameters for the governments are all set to $0.9^{\mathbf{4}}\left(=\boldsymbol{\rho}_{\mathbf{1}}=\boldsymbol{\rho}_{\mathbf{2}}=\boldsymbol{\rho}_{c}\right)$. The number of bankers is set to $\boldsymbol{\omega}_{B, \mathbf{1}}=\boldsymbol{\omega}_{B, \mathbf{2}}=\mathbf{0 . 0 0 5}$.

To make the difference between the two regions explicit, we assume that region 1 is a labor-intensive economy $\left(\alpha_{1}=1 / 4\right)$ and region 2 is a capital-intensive economy $\left(\alpha_{2}=5 / 12\right)$. In this setting, $\frac{\alpha_{1}+\alpha_{2}}{2}=1 / 3$. We also assume that only region 1 's social capital is effective $\left(\eta_{1}=0.2, \eta_{2}=0\right)$. Furthermore, the number of non-optimizing agents is set to $\omega_{1}=0.4$ and $\omega_{2}=0.3$, respectively. ${ }^{6,7}$ The elasticity of the non-default rate with respect to debt is set to $v_{1}=0.03, v_{2}=0.1$, and $v_{c}=0$, respectively.

\footnotetext{
${ }^{6}$ Using European data, Coenen and Straub (2005), Forni et al. (2009), and Ratto et al. (2009) estimate the share of non-Ricardian households in a DSGE framework with the technique introduced by Smets and Wouters (2003). The estimated value is between 0.2 and 0 .
}

(C) Southern Regional Science Association 2013. 


\section{SIMULATION ANALYSIS}

We conduct four types of simulations: (i) the government of region 1 implements a fiscal expansion policy in its own region; (ii) the government of region 2 implements a fiscal expansion policy in its own region; (iii) the central government implements a fiscal expansion policy in region 1; and (iv) the central government implements a fiscal expansion policy in region 2 . Note that the simulations are conducted on the log-linearized version of our model constructed in Section 3.

Figures $1,2,3$, and 4 represent impulse responses to the shocks of $\varepsilon_{t}^{1}, \varepsilon_{t}^{2}, \varepsilon_{t}^{c, 1}$, and $\varepsilon_{t}^{c, 2}$ in Eqs (29) and (30), whose values are set to $1 \%$ of the national output. In all cases, the first year's national output rises by more than $1 \%$ because of the positive consumption response. This positive response is due to the existence of non-Ricardian households. Furthermore, labor increases due to the inter-temporal substitution effect of increasing interest rates, and this increase in interest rates also leads to a fall in investment.

The time path of the output differs depending on whether or not social capital is effective. When there is fiscal expansion in region 1, which has effective social capital, the output continues to increase, because social capital directly increases output. This is confirmed in Figure 1 (Case (i)) and Figure 3 (Case (iii)). However, when the policy is implemented in region 2 , where social capital is ineffective, the output decreases, except in the first period, as shown in Figure 2 (Case (i)) and Figure 4 (Case (iv)).

Thus, the qualitative properties of the effects of fiscal policy are similar if the policy is implemented in the same region, by whichever government, but the quantitative properties are not. To see which government's fiscal policy has a larger effect, we depict the impulse response of outputs for all four cases in Figure 5. We see that the effect in Case (iii), in which the central government implements the fiscal expansion policy, is the largest. The fiscal multiplier in the first year in this case is not as large as that in the other cases, as shown Table 2, which displays the fiscal multipliers for the first year.

In Case (i), the local government in region 1 faced a risk premium in issuing their bonds. This leads to an increase in interest rates, which results in a large crowding out relative to Case (iii). The time paths of the output in Cases (ii) and (iv) are similar, but their first year multipliers are slightly different. This is because the increase in central government debt raises the tax burden in both regions. On the other hand, when the local government in region 2 implements the fiscal expansion, the tax increase only occurs in region 2 , which has fewer non-Ricardian households than region 1.

As shown above, the fiscal multipliers depend on who implements the policy and where the policy is implemented. Our results confirm that the effect of fiscal expansion is largest when a more solvent government implements a fiscal policy in a region where social capital is productive and the number of non-Ricardian households is large.

\footnotetext{
${ }^{7}$ One may consider that region 1 exhibits increasing returns to scale due to social capital and enjoy higher profits, and therefore region 1 may have fewer non-Ricardian households if households that earn less income would be likely to be non-Ricardian. At this point, note that, in our simulation, the steady-state output of both regions is normalized to one.
}

(C) Southern Regional Science Association 2013. 


\section{Figure 1: Impulse responses in Case (i)}

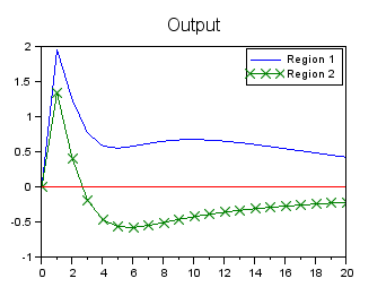

Local government spending

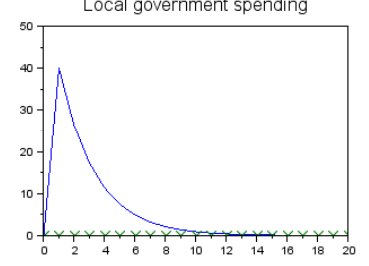

Central government debt

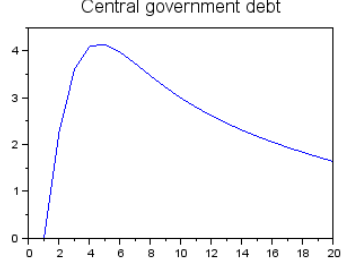

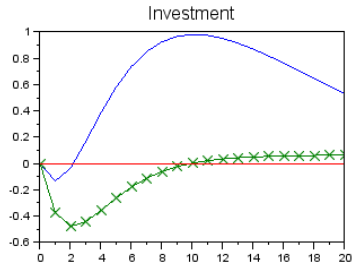

Central government spending

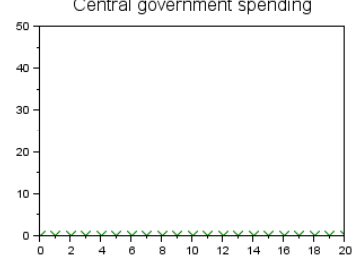

Interest rate for local government debt

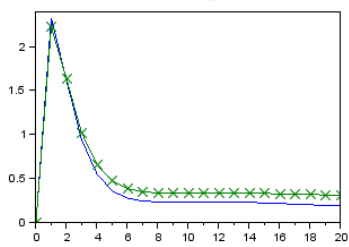

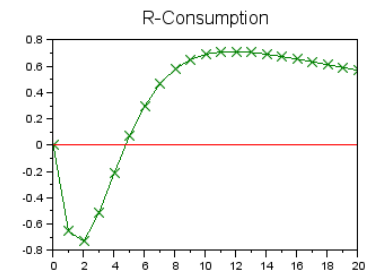

Hours worked

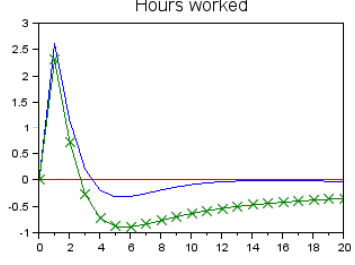

Interest rate for central government debt

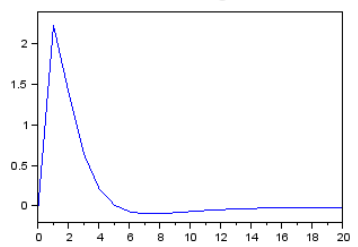

NR-Consumption

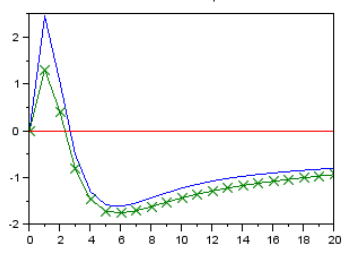

Local government debt

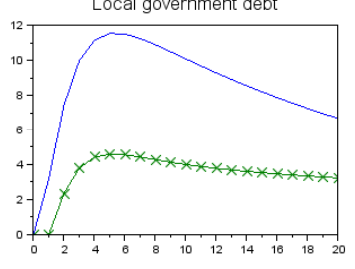

National output

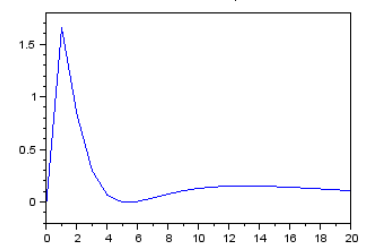

Note: Figure 1 indicates impulse responses to a local government spending shock in region 1, set to $1 \%$ of national output. Each line depicts the saddle path of the percentage deviation from the steady state. In the above figure, "R-Consumption" and "NRConsumption" represent the consumption of Ricardian and non-Ricardian households, respectively.

Figure 2: Impulse responses in Case (ii)

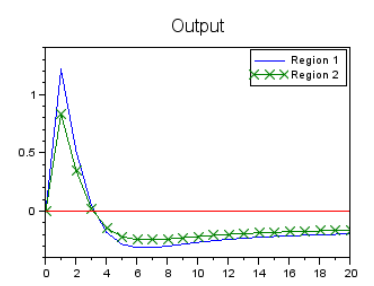

Local government spending

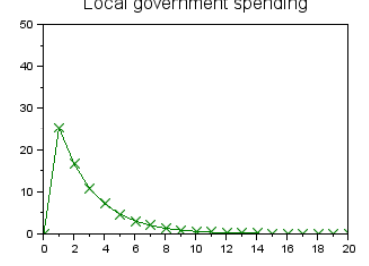

Central government debt

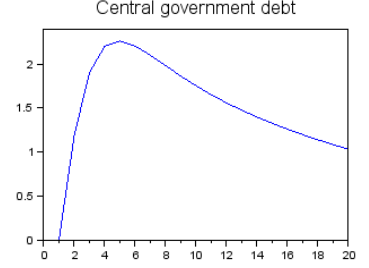

Investment

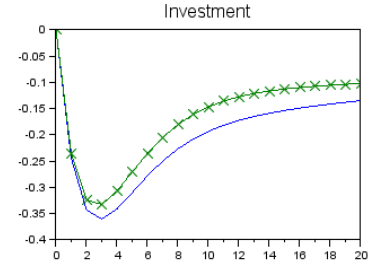

Central government spending

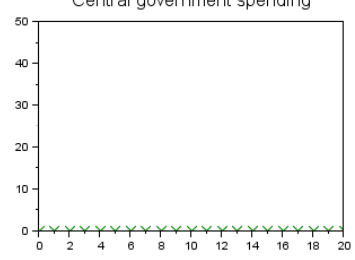

Interest rate for local governemnt debt

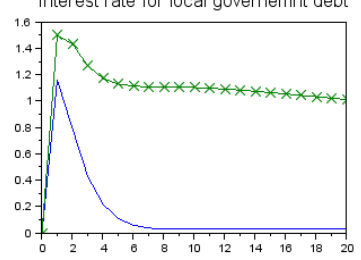

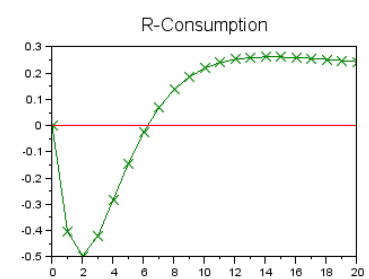

Hours worked

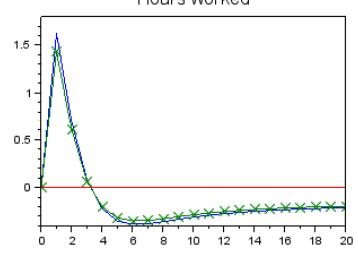

Interest rate for central government debt

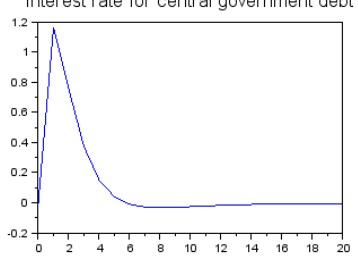

NR-Consumption

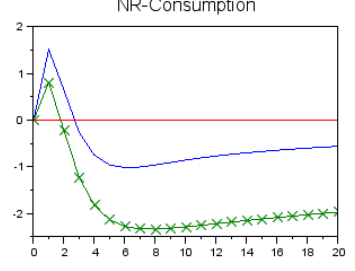

Local government debt

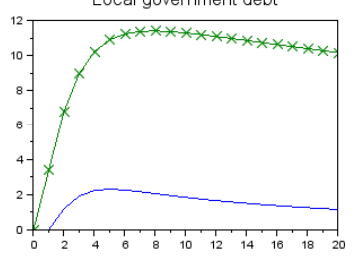

National output

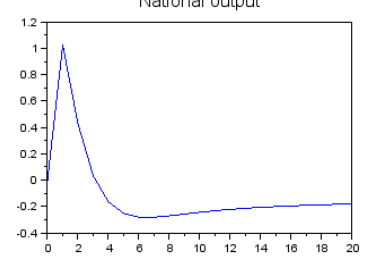

Note: Figure 2 indicates impulse responses to a local government spending shock in region 2, set to $1 \%$ of national output. Each line depicts the saddle path of the percentage deviation from the steady state. In the above figure, "R-Consumption" and "NRConsumption" represent the consumption of Ricardian and non-Ricardian households, respectively. 
Figure 3: Impulse responses in Case (iii)

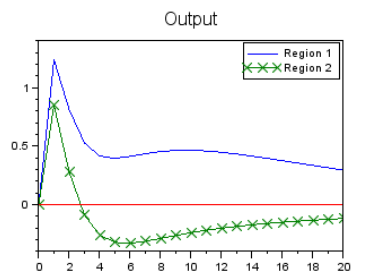

Local government spending

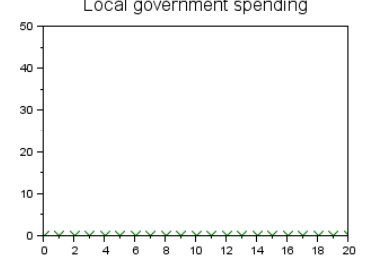

Central government debt

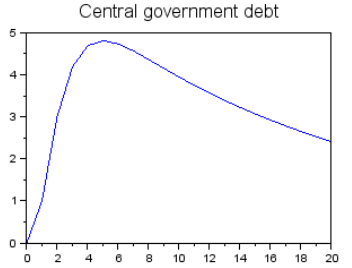

Investment

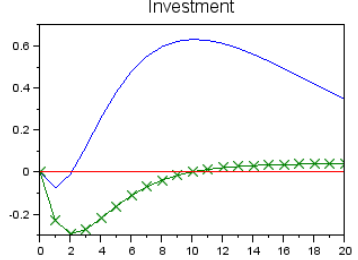

Central government spending

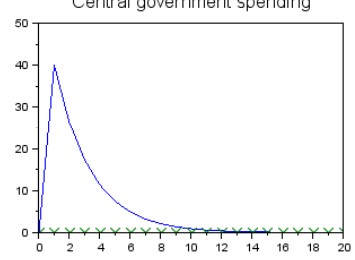

Interest rate for local governemnt debt

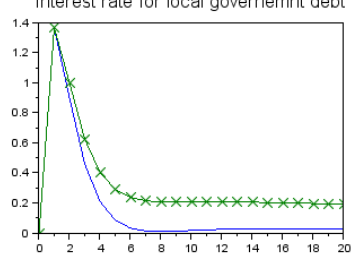

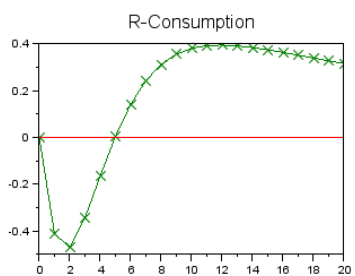

Hours worked

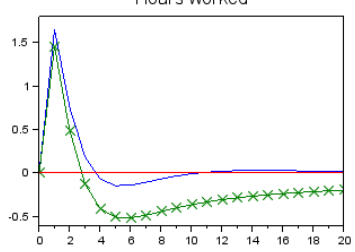

Interest rate for central government debt

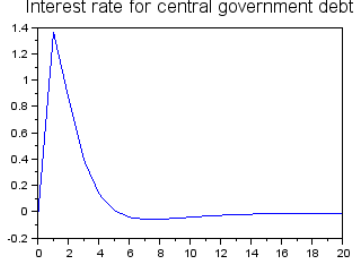

NR-Consumption

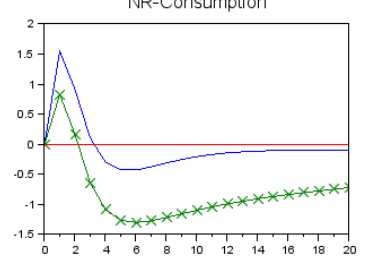

Local government debt

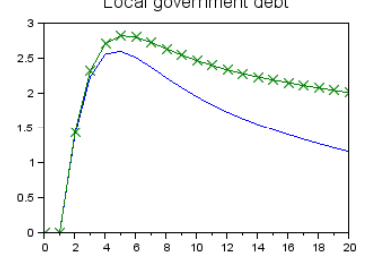

National output

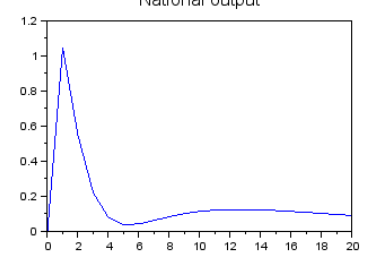

Note: Figure 3 indicates impulse responses to a central government spending shock in region 1 , set to $1 \%$ of national output. Each line depicts the saddle path of the percentage deviation from the steady state. In the above figure, "R-Consumption" and "NR-Consumption" represent the consumption of Ricardian and non-Ricardian households, respectively.

Figure 4: Impulse responses in Case (iv)

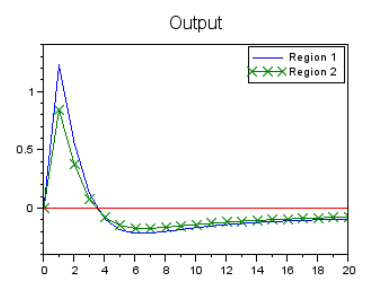

Local government spending

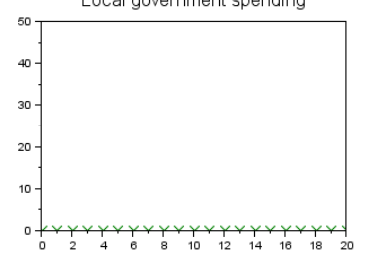

Central government debt

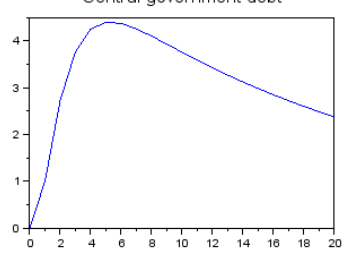

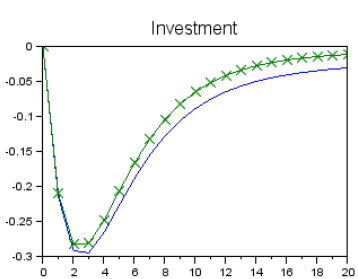

Central government spending
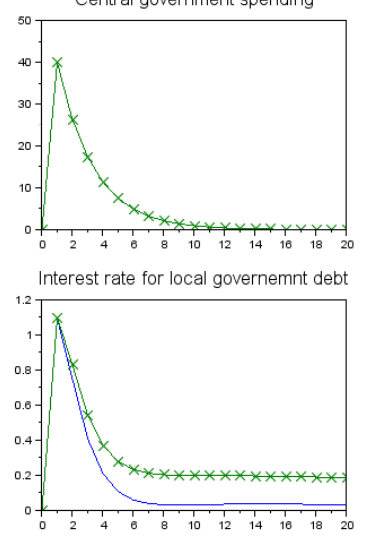

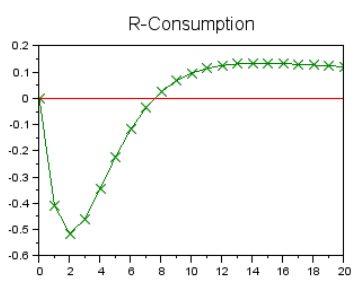

Hours worked

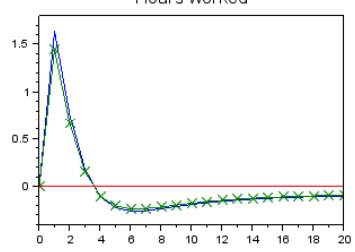

Interest rate for central government debt

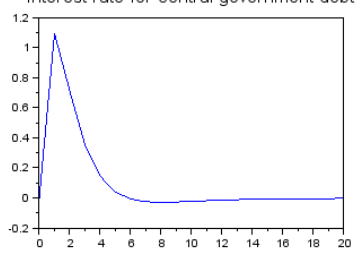

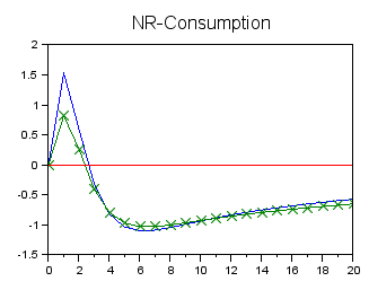

Local government debt

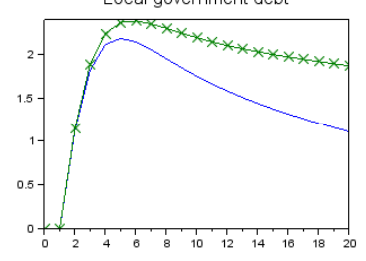

National output

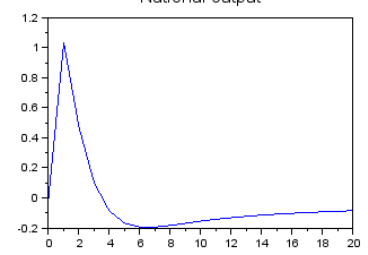

Note: Figure 4 indicates impulse responses to a central government spending shock in region 2, set to $1 \%$ of national output. Each line depicts the saddle path of the percentage deviation from the steady state. In the above figure, "R-Consumption" and "NR-Consumption" represent the consumption of Ricardian and non-Ricardian households, respectively. 
Figure 5: Impulse responses of output in all cases.

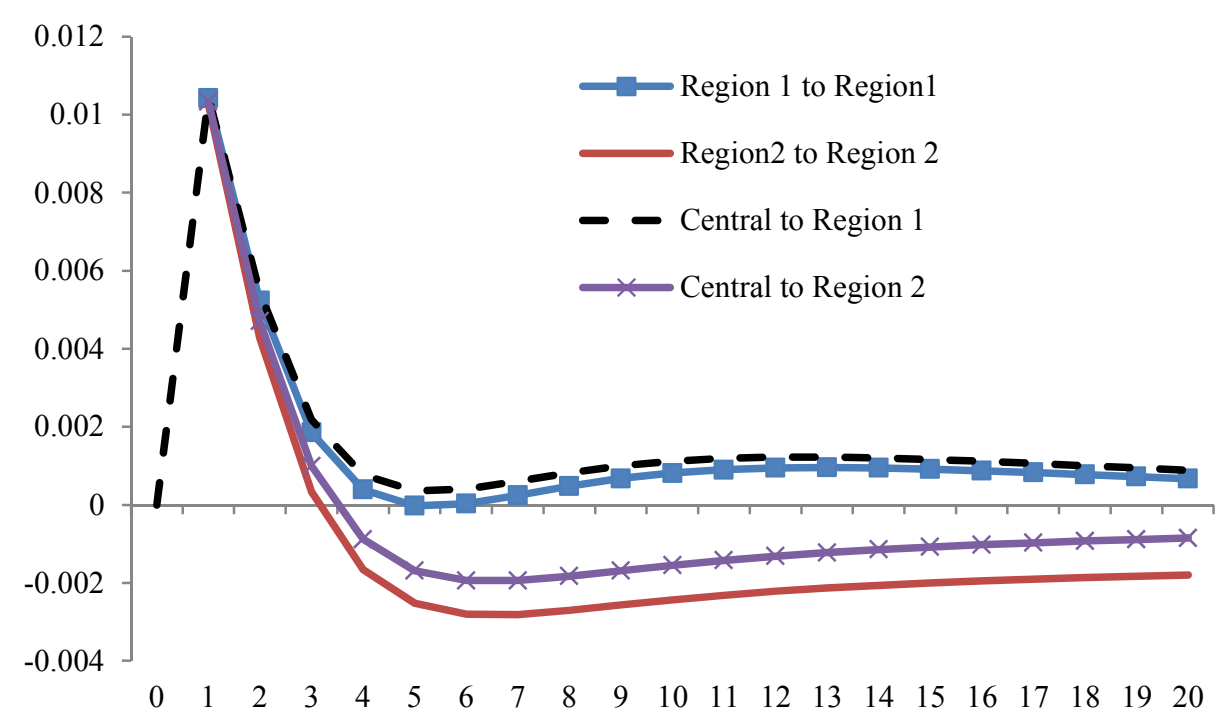

Table 2: Fiscal Multipliers in the First Year

\begin{tabular}{llc}
\hline \hline \multicolumn{1}{c}{ Case } & & Fiscal multipliers \\
\cline { 1 - 1 } (i) & & 1.0424 \\
(ii) & & 1.0250 \\
(iii) & & 1.0445 \\
(iv) & 1.0331 \\
\hline \hline
\end{tabular}

\section{AN ILLUSTRATION: A FISCAL CRISIS}

Since the 2008 financial crisis, we have faced another crisis; a fiscal crisis. In this section, we try to grasp the economic effects of this fiscal crisis. Here, we interpret the fiscal crisis as a sudden rise in interest rates on government bonds. It is interesting to investigate how some regions' fiscal problems affect the economy of other regions, as well as the national economy. To this end, we introduce an information shock with regard to government solvency, as follows:

$$
E_{t}\left[\log \left(1-p_{t+1}^{i}\right)\right]=\text { const. }-v_{i} \log B_{t+1}^{i}-\varepsilon_{t}^{p, i}
$$

where $\varepsilon_{t}^{p, i}$ represents an i.i.d. shock with a mean of 0 and an information shock with regard to local government $i$ 's solvency.

Figure 6 shows the impulse responses to the shock of $\varepsilon_{t}^{p, 2}$ in the two-region model. We confirm that the local government bond interest rates in region 1 rise in period 1 because of the increase in risk premiums. In period 2, region 1's government has to issue more bonds to finance the payment of increased interest rates, and this in turn leads to an increase in interest rates in the region. By arbitrage, interest rates for the central government and local government bonds in region 2 also increase. In the next period, there is an increase in tax in region 1, and the consumption of non-Ricardian households decreases. The higher risk premium for the local tax in region 1 decreases the supply of bonds in region 1, which leads to a decline in deposit rates.

(C) Southern Regional Science Association 2013. 
Therefore, the consumption by Ricardian households increases. The decrease in deposit rates has a negative effect on work, and output decreases.

Thus, information about government solvency has an effect on the real economy. Therefore, governments have to plan their fiscal policy in such a manner that it does not cause economic agents to expect a fiscal crisis.

\section{CONCLUDING REMARKS}

We developed a DSGE model in which a country is divided into several regions, and we simulated a two-region version of this regional DSGE model to evaluate the effects of a fiscal policy. To show the differences between the regions explicitly, we assume that region 1's economy is labor intensive, has a large number of non-Ricardian households, and faces a low

Figure 6: Impulse Responses to a Shock of $\varepsilon_{t}^{p, 2}$
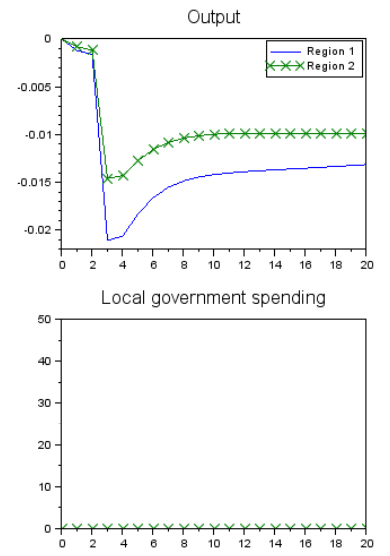

Central government debt

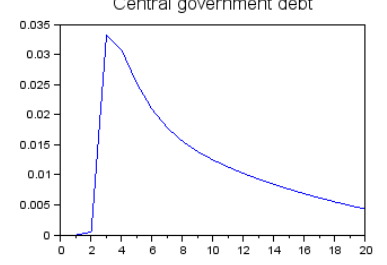

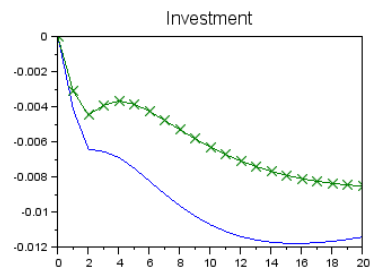

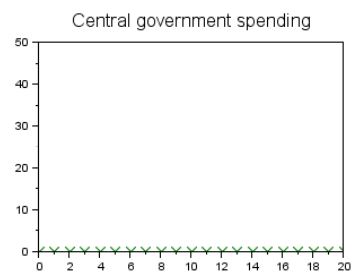

Interest rate for local governemnt debt

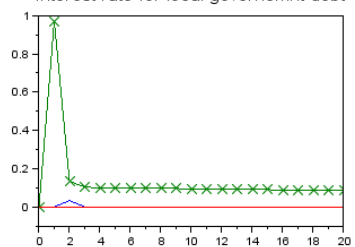

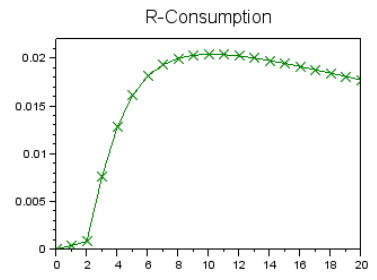
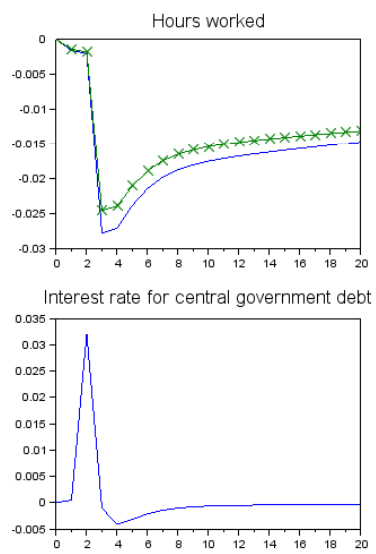
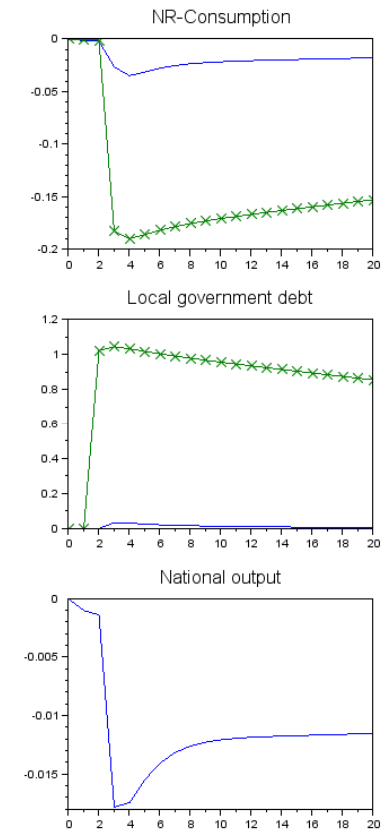

Note: Figure 6 indicates impulse responses to the shock of information of local government i's solvency. Each line depicts the saddle path of the percentage deviation from the steady state. In the above figure, "R-Consumption" and "NR-Consumption" represent the consumption of Ricardian and non-Ricardian households, respectively.

risk premium in issuing bonds. From the simulation results, we found that the effects of fiscal expansion is largest if a more solvent government implements the policy in a region where social capital is productive and the number of non-Ricardian households is large. Moreover, we illustrated a fiscal policy using our model. We interpret a crisis as a sudden rise in interest rates on government bonds caused by a sudden increase in the probability of a government defaulting. We found that this leads to a decrease in national output.

As a future task, we need to allow for a household to move to a different region, along with its optimal choice, based on the spirit of Tiebout (1956). Furthermore, our one-good economy may have to be extended to an economy with several goods because, in the actual economy, some goods in one region are inputs for the production in other regions. 


\section{REFERENCES}

Baxter, Marianne and Robert G. King. (1993) "Fiscal Policy in General Equilibrium," American Economic Review, 92, 571-589.

Beetsma, Roel and Massimo Giuliodori. (2011) "The Effects of Government Purchases Shocks: Review and Estimates for the EU," Economic Journal, 121, F5-F32.

Benigno, Pierpaolo. (2004) "Optimal Monetary Policy in a Currency Area," Journal of International Economics, 63, 293-320.

Blanchard, Olivier and Roberto Perotti. (2002) “An Empirical Characterization of the Dynamic Effects of Changes in Government Spending and Taxes on Output," Quarterly Journal of Economics, 117, 1329-1368.

Christiano, Lawrence J., Martin Eichenbaum, and Charles Evans. (2005) "Nominal Rigidities and the Dynamic Effects of a Shock to Monetary Policy," Journal of Political Economy, $113,1-45$.

Coenen, Günter and Roland Straub. (2005) "Does Government Spending Crowd in Private Consumption? Theory and Empirical Evidence from the Euro Area," International Finance, 8, 435-470.

Forni, Lorenzo, Libero Monteforte, and Luca Sessa. (2009) "The General Equilibrium Effects of Fiscal Policy: Estimates for the Euro Area," Journal of Public Economics, 93, 559-585.

Fujita, Masahisa and Paul Krugman. (2004) "The New Economic Geography: Past, Present and the Future," Papers in Regional Science, 83, 139-164.

Fujita, Masahisa and Tomoya Mori. (2005) "Frontiers of the New Economic Geography," Papers in Regional Science, 84(3), 377-405.

Galí, Jordi and Tommaso Monacelli. (2008) "Optimal monetary and fiscal policy in a currency union,” Journal of International Economics, 76, 116-132.

Galí, Jordi, Javier Valles, and J. David Lopez-Salido. (2007) "Understanding the Effects of Government Spending on Consumption," Journal of the European Economic Association, 5, 227-250.

Linnemann, Ludger. (2006) "The effect of Government Spending on Private Consumption: A Puzzle?” Journal of Money, Credit, and Banking, 38, 1715-1735.

Lombardo, Giovanni. (2006) "Inflation Targeting Rules and Welfare in an Asymmetric Currency Area," Journal of International Economics, 68(2), 424-442.

Monacelli, Tommaso, Roberto Perotti, and Antonella Trigari. (2010) "Unemployment Fiscal Multipliers," Journal of Monetary Economics, 57, 531-553.

Mountford, Andrew and Harald Uhlig. (2009) "What are the Effects of Fiscal Policy Shocks?" Journal of Applied Econometrics, 24, 960-992.

Ramey, Valerie A. (2011) "Identifying Government Spending Shocks: It's All in the Timing," The Quarterly Journal of Economics, 126(1), 1-50. 
Ratto, Marco, Werner Roeger, and Jan in 't Veld. (2009) "QUEST III: An Estimated OpenEconomy DSGE Model of the Euro Area with Fiscal and Monetary Policy," Economic Modelling, 26, 222-233.

Ravn, Morten, Stephanie Schmitt-Gorohe, and Martin Uribe. (2006) "Deep habits," Review of Economic Studies, 73, 195-218.

Smets, Frank and Raf Wouters. (2003) “An Estimated Dynamic Stochastic General Equilibrium Model of the Euro Area," Journal of the European Economic Association, 20, 11231175.

Tiebout, Charles M. (1956) "A Pure Theory of Local Expenditures," Journal of Political Economy, 64, 416-424. 